\title{
RESPONS PERTUMBUHAN DAN AKTIVITAS ENZIM AMILASE BENIH IKAN BANDENG (Chanos chanos Forsskal) YANG DIBERI PAKAN DENGAN KANDUNGAN KARBOHIDRAT YANG BERBEDA
}

\author{
Muhammad Marzuqi*|\#, I Wayan Kasa*), dan Nyoman Adiasmara Giri* \\ *) Balai Besar Riset Budidaya Laut dan Penyuluhan Perikanan \\ Jl. Br. Gondol, Kec. Gerokgak Kab. Buleleng, Kotak Pos 140, Singaraja 81101, Bali \\ *) Program Studi Biologi, Program Pascasarjana, Universitas Udayana, Den pasar, Bali \\ JI. Raya Kampus UNUD, Bukit Jimbaran, Kuta Selatan, Badung 80361, Bali
}

(Naskah diterima: 25 M ei 2018; Revisi final: 21 Maret 2019; Disetujui publikasi: 21 Maret 2019)

\begin{abstract}
ABSTRAK
Karbohidrat dalam pakan memiliki peranan penting untuk menunjang pertumbuhan ikan bandeng sehingga perlu diketahui kandungan yang optimal. Tujuan penelitian ini adalah untuk mengetahui pengaruh kandungan dektrin sebagai sumber karbohidrat dalam pakan terhadap laju pertumbuhan, efisiensi pakan, dan aktivitas enzim amilase ikan bandeng. Pakan percobaan mempunyai kandungan karbohidrat berbeda yaitu 3,4\% 12,4\% 21,4\% 30,4\% 39,4\% dan pakan dibuat dalam bentuk pelet kering dengan diameter 2,1$3,1 \mathrm{~mm}$. Ikan uji yang digunakan yaitu benih ikan bandeng berbobot $1,5 \pm 0,5 \mathrm{~g}$ dengan panjang total 8,0 $\pm 0,5 \mathrm{~cm}$, ditebar dengan kepadatan 20 ekor/bak. Wadah yang digunakan berupa 15 bak polikarbonat bervolume 400 liter dan dilengkapi aerasi dengan sistem air mengalir. Percobaan dirancang dengan rancangan acak lengkap, lima perlakuan dan tiga ulangan. Parameter yang diamati adalah laju pertumbuhan, efisiensi pakan, dan aktivitas enzim amilase. Data yang diperoleh dianalisis secara statistik dengan menggunakan analisis keragaman (ANOVA). Hasil penelitian menunjukkan kandungan karbohidrat dalam pakan berpengaruh terhadap laju pertumbuhan, efisiensi pakan, dan aktivitas enzim amilase benih ikan bandeng $(P<0,05)$. Pakan dengan karbohidrat $30,4 \%$ optimal untuk mendukung laju pertumbuhan $(0,364$ g/hari), efisiensi pakan $(110,69 \%$, dan aktivitas enzim amilase diperoleh sebesar 2,614 unit/menit.mL pada lambung dan 2,605 unit/menit.mL pada usus benih ikan bandeng.
\end{abstract}

KATA KUNCl: kadar karbohidrat; pakan; pertumbuhan; aktivitas enzim amilase

ABSTRACT: The growth response and amylase enzyme activities in milkfish fry (Chanos chanos Forsskal ) fed with diets containing different carbohydrate dosages. By: Muhammad Marzuqi, I Wayan Kasa, and Nyoman Adiasmara Giri

\begin{abstract}
Carbohydrates in commercial diets for milkfish fry have an important role in supporting the growth of the fish. The purpose of this experiment was to determine the effects of different dectrine contents in feed as a source of carbohydrate on the growth response, feed efficiency, and amylase enzyme activity of milkfish fry. The experimental feed was formulated in form of 2.1 - $3.1 \mathrm{~mm}$ diameter of dry pellets containing different carbohydrate contents, namely $3.4 \%$ $12.4 \% 21.4 \% 30.4 \% 39.4 \%$ The fish used was milkfish fry with an average weight of $1.5 \pm 0.5 \mathrm{~g}$ and length of 8.0 $\pm 0.5 \mathrm{~cm}$ and stocked with a density of 20 fish/tank. The experiment used 15 polycarbonate tanks filled with 400 liters of seawater and aerated with a flowing water system. The experiment was arranged in a completely randomized design with five treatments and three replications. The parameters observed were growth rate, feed efficiency, and amylase enzyme activity. The results showed that carbohydrate differences in the diets affected the growth rate, feed efficiency, and amylase enzyme activity of milkfish fry. The diet with $30.4 \%$ carbohydrate content produced the optimum finfish fry growth rate $(0.364 \mathrm{~g} / \mathrm{day})$, and feed efficiency $(110.69 \%$. The measured amylase enzyme activity was 2.614 units/minute $\mathrm{mL}$ in the stomach and 2,605 units/minute. $\mathrm{mL}$ in the intestine milkfish fry.
\end{abstract}

\section{KEYWORDS: carbohydrate requirement; diet; growth rate; amylase enzyme activity}

\footnotetext{
\# Korespondensi: Balai Besar Riset Budidaya Laut dan

Penyuluhan Perikanan. JI. Br. Gondol, Kec. Gerokgak

Kab. Buleleng, Kotak Pos 140, Singaraja 81101, Bali, Indonesia

Tel.: + 6236292278

E-mail: marzuqi_rim@yahoo.co.id
} 


\section{PENDAHULUAN}

Teknologi budidaya ikan bandeng di tambak mengalami perkembangan yang begitu pesat mulai dari sistem tradisional sampai sistem intensif. Pada budidaya intensif, pakan merupakan salah satu komponen yang sangat besar peranannya untuk mencapai pertumbuhan yang optimal. Salah satu kendala dalam upaya intensifikasi budidaya ikan khususnya ikan bandeng adalah harga pakan yang relatif mahal sehingga total biaya produksi cukup tinggi di mana dapat mencapai 35\%60\% (Sutikno, 2011). Terjadinya peningkatan harga pakan ikan yang tinggi disebabkan oleh sebagian besar bahan baku penyusun pakan terutama sumber protein masih diperoleh dari impor. Harga pakan ikan bandeng yang relatif mahal ini disebabkan oleh kandungan proteinnya. Protein merupakan sumber utama nutrien untuk pertumbuhan, terutama protein yang berasal dari tepung ikan. Dalam penyusunan pakan ikan maka tepung ikan sebagai sumber protein yang ketersediaanya terbatas dan bahkan masih harus diimpor.

Pakan ikan yang baik memiliki kandungan nutrien yang sesuai dengan kebutuhan ikan yang dibudidayakan. Pakan harus memiliki keseimbangan antara protein, lemak, dan karbohidrat untuk mensuplai energi, proses fisiologi, dan biokimia setiap jenis dan ukuran ikan (NRC, 1983). Ikan bandeng dapat tumbuh lebih cepat dengan diberi pakan pelet dengan kadar protein 25\%35\%(Buwono, 2000). Menurut Boonyaratpalin (1997), kebutuhan protein pakan benih ikan bandeng pada ukuran 0,5-0,8 g berkisar 30\%40\% Tingginya kebutuhan protein akan berimplikasi pada harga pakan yang mahal, serta banyaknya limbah nitrogen ke perairan lingkungan budidaya. NRC (1983) mengemukakan bahwa protein merupakan zat terpenting dari semua zat gizi yang diperlukan ikan karena merupakan zat penyusun dan sumber energi utama bagi ikan.

Salah satu upaya untuk mengurangi peranan protein sebagai sumber energi dalam pakan adalah dengan memaksimalkan penggunaan karbohidrat pakan sebagai sumber energi. Kemampuan ikan untuk memanfaatkan karbohidrat tergantung pada kemampuan menghasilkan enzim amilase sebagai pemecah karbohidrat. Pakan yang mengandung karbohidrat dan lemak yang tepat dapat mengurangi penggunaan protein sebagai sumber energi yang dikenal sebagai protein sparing effect. Terjadinya protein sparing effect akan dapat menurunkan biaya produksi pakan menjadi lebih murah dan mengurangi limbah nitrogen yang masuk ke lingkungan (Peres \& Teles, 1999). Karbohidrat adalah salah satu makro nutrien yang cukup penting dalam pakan ikan, merupakan sumber energi pakan yang paling murah dibanding protein dan lemak (Erfanullah \& Jafri, 1995). Salah satu jenis karbohidrat yang dalam formula pakan adalah dektrin. Dektrin merupakan substrat kesukaan bakteri acidophilik dalam saluran pencernaan dan apabila pakan mengandung dektrin maka sintesis vitamin B dalam usus akan meningkat (Winarno, 1997). Karbohidrat dalam bentuk sederhana umumnya memiliki sifat lebih mudah larut dalam air daripada lemak dan protein (Mashur, 2005). Pada ikan channel cat fish dapat memanfaatkan dektrin dan tepung jagung sebagai sumber karbohidrat dalam pakan dengan lebih baik daripada menggunakan glukosa, fruktosa, maltosa, dan sukrosa. Sementara, Buhler \& Halver (1961) dalam Wilson (1994), melaporkan bahwa pemberian pakan dengan sumber karbohidrat yang berbeda pada pakan chinook salmon muda (Oncorhynchus tschawytscha) dengan kadar 20,00\% ternyata glukosa, maltosa, dan sukrosa menghasilkan laju pertumbuhan yang lebih baik dibandingkan dengan dektrin, fruktosa, galaktosa, tepung singkong, dan glukosamin.

Pemanfaatan karbohidrat pada ikan mas dapat mencapai 40\%(Furuichi, 1988), sedangkan pada ikan gurami ukuran $30 \mathrm{~g}$ mampu mencerna dan menyerap karbohidrat (soluble carbohydrate) sampai kadar 35,59\% dan menghasilkan retensi, laju pertumbuhan, dan efisiensi pakan tertinggi pada karbohidrat 20,81\% (Hadadi, 2009).

Di samping itu, untuk meningkatkan efisiensi pakan dan mengoptimalkan pertumbuhan ikan perlu diperhatikan manajemen pemberian pakan. Pemberian formula pakan buatan yang sesuai dan waktu yang tepat akan dapat meningkatkan kecernaan dan penyerapan nutrien pakan dalam saluran pencernaan ikan. Hal ini berdampak pada peningkatan pertumbuhan dan kelangsungan hidup ikan. Salah satu yang perlu diketahui adalah aktivitas enzim dalam saluran pencernaan ikan bandeng. Kemampuan ikan dalam mencerna pakan sangat tergantung pada kelengkapan organ pencernaan dan ketersediaan enzim pencernaan. Jenis dan jumlah enzim yang disekresikan oleh suatu jenis ikan berkaitan sangat erat dengan keberadaan kelenjar tersebut dan akan mengalami perkembangan sejalan dengan peningkatan umur dan kesempurnaan kelenjar pencernaan itu sendiri (Affandi et al., 2005). Peningkatan ini disebabkan oleh semakin sempurnannya organ penghasil enzim. Akan tetapi, untuk beberapa jenis enzim akan menurun sesuai dengan kebiasaan makanan dari ikan (Infante $\&$ Cahu, 2001). Menurut Bagarinao (1991), ada keterkaitan antara aktivitas enzim pencernaan dan perkembangan struktur organ pencernaan dan kebiasaan makan dari ikan bandeng. Enzim amilase merupakan enzim yang menghidrolisis karbohidrat. Amilase secara bertahap 
akan menghidrolisis polisakarida menjadi monosakarida yang siap untuk diserap tubuh. Pada ikan, enzim ini terdapat di dalam lambung, pankreas, dan intestine (Dorit et al., 1991; McFadden \& Keeton, 1995; Nelson \& Robinson, 1982; Lewis, 1998; Purves et al., 1992; Starr \& Taggart, 1995; Wallace et al., 1996; Wilbraham \& Matta, 1992).

Mengingat pentingnya peran karbohidrat dalam pakan maka perlu dilakukan penelitian untuk menentukan kebutuhan karbohidrat, sebagai sumber energi untuk mendukung pertumbuhan, efisiensi pakan, dan pengaruhnya terhadap aktivitas enzim amilase pada benih ikan bandeng.

\section{BAHAN DAN METODE}

\section{Pakan Uji}

Percobaan dirancang menggunakan rancangan acak lengkap dengan lima perlakuan yaitu kadar karbohidrat yang berbeda dan setiap perlakuan terdiri atas tiga ulangan. Percobaan dilakukan di Balai Besar Riset Budidaya Laut dan Penyuluhan Perikanan, Gondol, Buleleng, Bali. Lima pakan diformulasi menggunakan tepung ikan dan kasein sebagai sumber protein. Sumber karbohidrat berupa dektrin dengan kadar karbohidrat pada perlakuan A $(3,4 \%), B(12,4 \%), C(21,4)$, $D(30,4 \%)$, dan $E(39,4)$. Bahan pakan uji berupa tepung ikan, kasein, dektrin, CMC, dan selulosa ditimbang sesuai dengan formulasi pada Tabel 1. Bahan-bahan tersebut dimasukkan ke dalam wadah plastik dan diaduk hingga merata, kemudian vitamin mix dan mineral mix yang sudah ditimbang dimasukkan ke dalam beaker glass lalu dicampur sedikit demi sedikit dengan bahan-bahan sebelumnya. Selanjutnya dimasukkan minyak ikan ke dalam ember sebagai sumber lemak dan dilakukan pengadukan hingga merata (homogen), setelah semua bahan tercampur rata, Ialu ditambahkan air sebanyak $\pm 30 \%$ dan diaduk secara merata hingga membentuk adonan kemudian dicetak dalam alat pencetak pakan (merk Royal) berukuran 2,1 mm dan 3,1 mm. Pakan yang sudah dikering dibungkus dengan plastik yang diberi kode perlakuan dan disimpan dalam kulkas pada suhu lebih kurang $4^{\circ} \mathrm{C}$.

\section{Hewan Uji dan Wadah Pemeliharaan}

Benih bandeng yang digunakan merupakan hasil pembenihan secara terkontrol dan berbobot rata-rata $1,5 \pm 0,5 \mathrm{~g}$ dan panjang total $8,0 \pm 0,5 \mathrm{~cm}$. Benih bandeng ditebar dengan kepadatan 20 ekor per bak. Uji pakan ini menggunakan 15 buah bak polikarbonat bervolume 400 liter. Setiap bak dilengkapi dengan aerasi dan sistem air mengalir dengan kecepatan 15 L/menit. Pakan diberikan tiga kali sehari pada pukul 08.00, 12.00, dan 16.00 WITA secara perlahan-lahan sampai kenyang (at satiation). Jumlah pakan yang diberikan dan sisa pakan dalam bak pemeliharaan dikumpulkan dan dikeringkan dalam oven untuk menghitung efisiensi pakan. Kotoran dalam setiap bak disiphon setiap pagi untuk mengoptimalkan kondisi air. Pengamatan pertumbuhan ikan uji dilakukan

Tabel 1. Komposisi pakan percobaan (\%bahan kering)

Table 1. Composition of experimental diet (\%dry matter)

\begin{tabular}{lccccc}
\hline & \multicolumn{5}{c}{ Pakan (kadar karbohidrat) / Diets (carbohidrate levels) (\%) } \\
\cline { 2 - 6 } \multicolumn{1}{c}{ Ingredients } & $\mathbf{A}$ & $\mathbf{B}$ & $\mathbf{C}$ & $\mathbf{D}$ & $\mathbf{E}$ \\
& $\mathbf{( 3 . 4 )}$ & $\mathbf{( 1 2 . 4 )}$ & $\mathbf{( 2 1 . 4 )}$ & $\mathbf{( 3 0 . 4 )}$ & $\mathbf{( 3 9 . 4 )}$ \\
\hline Tepung ikan (Fish meal) & 39.5 & 39.5 & 39.5 & 39.5 & 39.5 \\
Kasein (Casein) & 9.0 & 9.0 & 9.0 & 9.0 & 9.0 \\
Dekstrin (Dextrin) & 0.0 & 9.0 & 18.0 & 27.0 & 36.0 \\
Minyak ikan (Fish oil) & 3.0 & 3.0 & 3.0 & 3.0 & 3.0 \\
Vitamin mix & 1.3 & 1.3 & 1.3 & 1.3 & 1.3 \\
Mineral mix & 1.7 & 1.7 & 1.7 & 1.7 & 1.7 \\
CMC & 2.0 & 2.0 & 2.0 & 2.0 & 2.0 \\
Celulosa (Cellulose) & 43.5 & 34.5 & 25.5 & 16.5 & 7.5 \\
\hline \multicolumn{1}{c}{ Total } & 100.0 & 100.0 & 100.0 & 100.0 & 100.0 \\
\hline Komposisi proksimat pakan (Proximate composition) & $(\% \mathrm{DM})$ & & & \\
Protein (Protein) & 33.1 & 32.6 & 33 & 33 & 32.5 \\
Lemak (Lipid) & 7.5 & 8.0 & 7.8 & 7.7 & 7.7 \\
Abu (Ash) & 8.3 & 8.0 & 8.0 & 7.4 & 7.7 \\
Serat kasar (Crude fiber) & 47.7 & 39 & 29.9 & 21.5 & 12.7 \\
Karbohidrat (Carbohydrate/BETN) & 3.4 & 12.4 & 21.4 & 30.4 & 39.4 \\
\hline
\end{tabular}


dengan penimbangan seluruh ikan secara individu setiap tujuh hari. Pengukuran kualitas air seperti suhu, oksigen terlarut, $\mathrm{pH}$, dan salinitas dilakukan setiap hari, sedangkan amoniak dan nitrit pengukurannya dilakukan pada awal penelitian dan setiap seminggu sebelum pergantian air. Percobaan berlangsung selama delapan minggu.

\section{Analisis Kimia dan Aktivitas Enzim Amilase}

Sampel berupa daging bandeng diambil sebanyak dua ekor pada awal dan akhir percobaan, Ialu dikeringkan dengan freeze dryer, kemudian dianalisis komposisi proksimatnya. Komposisi proksimat pakan percobaan dianalisis di Laboratorium Nutrisi dan Pakan, Balai Besar Riset Budidaya Laut dan Penyuluhan Perikanan Gondol berdasarkan metode AOAC (1990) dan Takeuchi (1988). Kadar air menggunakan metode gravitasi, kandungan protein dengan metode Kjeldal, kadar air dengan metode ekstraksi menggunakan chloroform-metanhol dan gravitasi, kadar abu dengan metode gravimetri setelah pembakaran bahan dalam tanur pada suhu $550^{\circ} \mathrm{C}$. Serat kasar ditentukan dengan gravimetri setelah contoh bahan dimasak pada larutan asam dan basa. Kadar karbohidrat (BETN) dihitung berdasarkan Takeuchi (1988).

Pengamatan aktivitas enzim amilase dilakukan dengan cara pengambilan sampel dari ekstrak isi lambung dan isi usus ikan bandeng sesaat sebelum pemberian pakan (jam ke-0), dan 9, 12, 15, 18 jam setelah pemberian pakan (Yamin et al., 2008). Sampel dari ekstrak isi lambung dan isi usus ditimbang, kemudian ditambahkan larutan buffer Tris (20 mM Tris $\mathrm{HCl}, 1 \mathrm{mM}$ EDTA, $10 \mathrm{mM} \mathrm{CaCl} 2, \mathrm{pH}$ 7,5) dengan perbandingan $10 \%$ selanjutnya dihaluskan. Sampel dimasukkan ke dalam tabung effendorf dan disentrifuge dengan kecepatan $12.000 \mathrm{rpm}$ selama 10 menit pada suhu $4^{\circ} \mathrm{C}$. Supernatan diambil untuk diukur aktivitas enzim amilasenya berdasarkan metode Worthington (1993) dalam Melianawati (2009) dan Yulintine (2012). Dalam analisis enzim amilase urutan kerjanya adalah sebagai berikut: (a) larutan pati $1 \%$ (dalam $20 \mathrm{mM}$ sodium fosfat $\mathrm{pH} 6,9$ ) yang terkandung $6,0 \mathrm{mM} \mathrm{NaCl}$ sebagai substrat; (b) kemudian dipipet larutan pati- $\mathrm{NaCl}$ di atas sebanyak $0,5 \mathrm{~mL}$ dimasukkan ke dalam tabung reaksi; (c) kemudian ditambahkan $0,5 \mathrm{~mL}$ sampel/contoh dan diinkubasi selama tiga menit pada suhu $95^{\circ} \mathrm{C}$ (waterbath); (d) ditambahkan larutan DNS sebanyak 0,5 mL kemudian diinkubasikan kembali pada suhu $95^{\circ} \mathrm{C}$ selama lima menit; (e) kemudian dibaca absorbansinya pada spektrofoto meter dengan panjang gelo mbang $540 \mathrm{~nm}$; (f) dilakukan tahapan pengerjaan yang sama dengan contoh/sampel, untuk deret standar maltosa dengan konsentrasi 0, 50, 100, 200, 300, $400 \mathrm{mg} / \mathrm{L}$. Satu unit amilase dinyatakan sebagai jumlah enzim yang terdapat pada satu gram sampel yang mengkatalis perubahan substrat menjadi maltose per menit. Satu unit aktivitas setara dengan $\mu \mathrm{M}$ maltose per menit. Sehingga satuan aktivitas enzim amilase untuk setiap ikan yang diambil datanya dalam penelitian ini adalah unit/menit.mL.

\section{Analisis Statistik}

Data pertumbuhan, efisiensi pakan, dan aktivitas enzim amilase ikan uji dianalisis secara statistik dengan menggunakan analisis keragaman (ANOVA). Apabila dari daftar sidik ragam diketahui bahwa perlakuan menunjukkan pengaruh berbeda nyata $(P<0,05)$, maka untuk membandingkan nilai antar perlakuan dilanjutkan dengan Uji Beda Nyata Terkecil (BNT). Analisis data menggunakan software IMB SPSS 20 for windows. Untuk data dalam bentuk persentase, sebelum dianalisis ragam (ANOVA) ditransformasi ke akar kuadrat (Bluman, 2012).

\section{HASIL DAN BAHASAN}

Hasil pengamatan terhadap laju pertumbuhan harian (LPH), efisiensi pakan (EP), dan sintasan pada ikan bandeng yang diberi pakan dengan kadar karbohidrat yang berbeda disajikan pada Tabel 2 .

Pada Tabel 2 terlihat bahwa perbedaan kandungan karbohidrat dalam pakan berpengaruh terhadap laju pertumbuhan ikan bandeng $(P<0,05)$. Pakan yang mengandung kadar karbohidrat 30,4\% (Pakan D) menghasilkan laju pertumbuhan harian tertinggi yaitu $0,364 \pm 0,01$. Sementara pertumbuhan terendah diperoleh pada ikan yang diberi pakan dengan kandungan karbohidrat 3,4\% (Pakan A). Hal ini menunjukkan kadar karbohidrat 30,4\%paling efisien dimanfaatkan sebagai sumber energi dibandingkan kadar karbohidrat lainnya, sehingga protein pakan paling banyak digunakan untuk sintesa protein tubuh yang tercermin dari pertumbuhan harian ikan bandeng (Chanos chanos Forsskal) yang paling tinggi pada kadar tersebut. Ikan bandeng yang digunakan pada penelitian ini termasuk ikan omnivora, yang ternyata kebutuhan karbohidratnya mencapai 30,4\% dalam pakan. Hal tersebut dimungkinkan karena ikan yang digunakan adalah stadia benih ikan bandeng. Secara alami pada stadia larva, ikan bandeng tergolong karnivora yang memakan zooplankton, kemudian pada stadia benih menjadi omnivora yang memakan zooplankton, diatom, dan bentos kecil, dan selanjutnya pada ukuran juvenil termasuk ke dalam golongan herbivora yang memakan alga filamen, alga, detritus, bentos kecil, dan bisa mengonsumsi pakan buatan berbentuk pelet. Pada saat dewasa, ikan bandeng 
Tabel 2. Laju pertumbuhan harian (LPH), efisiensi pakan (EP), dan sintasan (SR) pada ikan bandeng selama 56 hari uji pakan

Table 2. Daily growth rate (LPH), feed efficiency (EP), and survival rate (SR) of milkfish during the experiment

\begin{tabular}{lccc}
\hline $\begin{array}{c}\text { Pakan (kadar karbohidrat) } \\
\text { Diets (carbohydrate leves) } \\
\text { (\% }\end{array}$ & $\begin{array}{c}\text { Laju pertumbuhan } \\
\text { harian (g/hari) } \\
\text { Daily growth rate (g/day) }\end{array}$ & $\begin{array}{c}\text { Efisiensi pakan } \\
\text { Feed efficiency (EP) } \\
(\%)\end{array}$ & $\begin{array}{c}\text { Sintasan } \\
\text { Survival rate } \\
(\%)\end{array}$ \\
\hline A $(3,4)$ & $0.297 \pm 0.02^{\mathrm{a}}$ & $95.01 \pm 6.02^{\mathrm{a}}$ & 98 \\
$\mathrm{~B}(12,4)$ & $0.320 \pm 0.01^{\mathrm{ab}}$ & $102.01 \pm 7.33^{\mathrm{a}}$ & 98 \\
$\mathrm{C}(21,4)$ & $0.356 \pm 0.02^{\mathrm{c}}$ & $105.61 \pm 6.24^{\mathrm{ab}}$ & 98 \\
$\mathrm{D}(30,4)$ & $0.364 \pm 0.01^{\mathrm{cd}}$ & $110.69 \pm 2.86^{\mathrm{b}}$ & 98 \\
$\mathrm{E}(39,4)$ & $0.337 \pm 0.01^{\mathrm{bcd}}$ & $98.93 \pm 1.25^{\mathrm{a}}$ & 100 \\
\hline
\end{tabular}

berubah menjadi omnivora lagi karena mengonsumsi algae mat, alga filamen, zooplankton, bentos lunak, dan pakan buatan berbentuk pelet (Bagarinao, 1991).

Pengaruh karbohidrat dalam pakan terhadap pertumbuhan ikan bergantung pada sumber, jenis, daya cerna, jumlah yang dimakan, kondisi lingkungan, dan jenis ikan (Brauge et al., 1994). Selain itu, respons pertumbuhan ikan terhadap karbohidrat pakan tergantung pada kemampuan organ pencernaan ikan dalam mencerna dan kemampuan sel untuk memanfaatkan glukosa (Watanabe, 1988). Kandungan karbohidrat pakan yang dapat dimanfaatkan secara optimal oleh ikan karnivora berkisar 10\%20\%, sedangkan pada ikan omnivora dapat memanfaatkan karbohidrat secara optimal pada tingkat 30\%40\%dalam pakan (Furuichi, 1988). Suwirya et al. (2002) melaporkan bahwa yuwana ikan kerapu bebek akan tumbuh dengan baik apabila diberikan pakan dengan dektrin sebagai sumber karbohidrat sekitar $8,21 \%$ $28,68 \%$ dengan kadar optimumnya adalah $15,66 \%$

Penggunaan karbohidrat pakan dipengaruhi oleh kekompleksan dan jumlah karbohidrat, jenis dan ukuran ikan budidaya (Podoskina et al., 1997). Nilai kecernaan karbohidrat pakan sangat dipengaruhi oleh kekompleksan sumber karbohidrat, jenis, dan ukuran ikan (Gallego et al., 1994; Shiau \& Chuang, 1995; Shiau, 1997). Nilai kecernaan dektrin pada ikan rainbrow trout sekitar $77,20 \%$ pada pakan yang mengandung dektrin $20 \%$ dan kecernaannya turun menjadi $45,40 \%$ dengan meningkatnya kandungan dektrin pakan menjadi $60,00 \%$ Sementara, pati yang telah dimasak memiliki nilai kecernaan sekitar $90 \%$ pada pakan yang mengandung pati sebesar $11,50 \%$ dan turun nilai kecernaannya menjadi 48,20\%dengan meningkatnya kandungan pati pakan menjadi 40,20\% (Inaba et al., 1963 dalam Usman, 2002). Penurunan Iaju pertumbuhan harian ikan bandeng dengan pakan berkadar karbohidrat 39,4\%(Pakan E) diduga karena kelebihan karbohidrat dalam pakan. Pada penelitian Moreira et al. (2008); Castro et al. (2016) melaporkan bahwa konsumsi karbohidrat yang tinggi biasanya akan meningkatkan pengendapan lemak dan glikogen pada ikan.

Perbedaan kadar karbohidrat dalam pakan berpengaruh terhadap efisiensi pakan ikan bandeng $(P<0,05)$. Pakan yang mengandung kadar karbohidrat $30,4 \%$ memiliki nilai efisiensi pakan tertinggi yaitu mencapai 110,69\% Efisiensi pakan didefinisikan sebagai nilai perbandingan antara pertambahan bobot ikan dengan bobot pakan yang dikonsumsi selama masa pemeliharaan yang dinyatakan dalam persen (Hepher, 1988). Efisiensi pakan digunakan untuk mengetahui jumlah pakan yang masuk kedalam sistem pencernaan ikan untuk berlangsungnya proses metabolisme dal am tubuh, salah satunya dimanfaatkan untuk pertumbuhan.

Semakin besar nilai suatu efisiensi pakan maka akan semakin tinggi pula tingkat pertumbuhannya (Wedemeyer, 1996). Selain itu, semakin tinggi efisiensi pakan maka semakin baik kualitas pakan yang digunakan. Efisiensi pakan tertinggi mencapai 110,69\% pada ikan bandeng yang diberi pakan dengan kadar karbohidrat 30,4\% Tingginya nilai efisiensi pakan pada ikan bandeng yang diberi pakan dengan kadar karbohidrat sebesar 30,4\%menunjukkan bahwa pada kadar karbohidrat tersebut paling efisien dimanfaatkan sebagai sumber energi non-protein dibandingkan kadar karbohidrat lainnya. Proses pencernaan pada kadar karbohidrat 30,4\%paling efisien dihidrolisa oleh enzim amilase menjadi maltosa pada segmen usus yang mempermudah proses selanjutnya oleh enzim laktase limit dekstrinase menjadi glukosa sehingga mudah 
diserap oleh kapiler darah. Glukosa dalam darah optimum digunakan untuk sumber energi pada ikan sehingga protein pakan banyak digunakan untuk sintesa protein tubuh yang tercermin dari pertumbuhan ikan bandeng yang paling tinggi pada kandungan karbohidrat tersebut. Hal ini didukung oleh Afrianto \& Liviawaty (2005) yang menyatakan bahwa pada prinsipnya, efisiensi pakan pada ikan tergantung pada tingkat penerimaan ikan dan enzim yang dimilikinya. Pada penelitian Ren et al. (2015) melaporkan bahwa juvenil ikan Megalobrama amblycephala diberi pakan dengan glukosa atau maltosa menunjukkan nilai feed efficiency ratio (FER) dan protein efficiency ratio (PER) lebih rendah bila dibandingkan dengan ikan yang diberi dekstrin dalam pakan. Nilai FER dan PER menunjukkan peningkatan yang jelas dengan meningkatnya kompleksitas karbohidrat yang mudah dicerna. Hal ini sesuai dengan laporan penelitian pada spesies ikan lainnya, seperti kobia (Rachycentroncanadum), Carassius auratus gibelio, flounder, dan gilthead sea bream (Cui et al., 2010; Enes et al., 2010; Lee et al., 2003; Tan et al., 2006).

Sintasan benih ikan bandeng yang diberi pakan dengan kadar karbohidrat berbeda selama delapan minggu berkisar $98 \% 100 \%$ Ikan yang mendapatkan pakan yang berukuran tepat dengan ukuran bukaan mulutnya akan dapat melangsungkan hidupnya dengan baik. Sintasan ikan bandeng (Chanos chanos Forsskal) didukung oleh manajemen pemeliharaan yang baik, pergantian air dalam bak pemeliharaan, faktor lingkungan, pakan, padat penebaran, umur, dan ukuran benih ikan saat ditebar (Marlyn \& Serrano, 2014).

Pengamatan aktivitas enzim amilase pada lambung maupun usus ikan bandeng (Chanos chanos Forsskal) disajikan dalam Gambar 1.

Perbedaan kandungan karbohidrat dalam pakan juga berpengaruh terhadap aktivitas enzim amilase baik di lambung maupun usus ikan bandeng $(P<0,05)$. Enzim amilase merupakan enzim yang menghidrolisis karbohidrat. Bentuk molekul karbohidrat yang paling sederhana terdiri atas satu molekul gula sederhana. Amilase secara bertahap akan menghidrolisis polisakarida menjadi monosakarida yang siap untuk diserap tubuh. Pada ikan bandeng, enzim ini terdapat di dalam lambung, pankreas, dan intestine. Aktivitas enzim á-amilase terus meningkat dengan meningkatnya umur. Aktivitas enzim á-amilase yang terus meningkat dengan bertambahnya umur ikan menunjukkan peningkatan kemampuan ikan untuk dapat memanfaatkan karbohidrat. Hal ini berhubungan dengan kebiasaan makanan selama siklus hidup ikan tersebut. Larva ikan bandeng memasuki stadia transisi pada umur 28 hari dan menjadi juvenil setelah berumur 35 hari (Bagarinao, 1991). Pada umur tersebut ikan bandeng bersifat omnivora dan dapat memanfaatkan karbohidrat lebih besar dibandingkan stadia sebelumnya. Enzim amilase mengubah zat tepung (amilum) menjadi maltose dan dekstrin. Maltose dan dekstrin dihidrolisa oleh enzim lactase limit dekstrinase menjadi glukosa yang dapat diserap oleh dinding sel usus.

Hasil penelitian menunjukkan bahwa aktivitas enzim amilase tertinggi kisaran waktu 15 jam setelah pemberian pakan pada organ lambung dan usus ikan bandeng. Rata-rata aktivitas enzim amilase di usus lebih tinggi dibandingkan lambung ikan bandeng. Hal ini sesuai dengan pendapat Bagarinao (1991) bahwa aktivitas amilase lebih banyak pada organ intestine (usus) ikan bandeng (Chanos chanos Forsskal). Hasil tersebut memperlihatkan perbedaan kadar karbohidrat dalam pakan berpengaruh terhadap aktivitas enzim amilase baik di lambung maupun usus ikan bandeng $(P<0,05)$. Pakan yang mengandung kadar karbohidrat $30,4 \%$ (Pakan D) memiliki nilai aktivitas enzim tertinggi yaitu sebesar 2,614 unit/menit.mL pada lambung dan 2,605 unit/menit.mL pada usus benih ikan bandeng. Hal ini menunjukkan pengaruh optimum kadar karbohidrat dalam pakan terhadap aktivitas enzim amilase adalah pada konsentrasi 30,4\% Penurunan aktivitas enzim amilase pada kadar karbohidrat 39,4\%diduga disebabkan karena kelebihan substrat menghambat aktivitas enzim. Hal ini juga berkaitan dengan nilai kecernaan sumber karbohidrat, aktivitas enzim karbokhidrase ikan, kemampuan penyerapan glukosa dan monosakarida lainnya, serta kemampuan sel memanfaatkan glukosa dalam darah (Hepher, 1988; Wilson, 1994).

Data pengukuran kualitas media penelitian dapat dilihat pada Tabel 3.

Dalam penelitian ini kualitas fisika dan kimia air selama penelitian selalu dipertahankan dalam kondisi yang sama untuk setiap bak dan sesuai dengan ukuran optimal yang menunjang kelangsungan hidup ikan bandeng.

\section{KESIMPULAN}

Kandungan karbohidrat (dektrin) yang berbeda dalam pakan berpengaruh terhadap laju pertumbuhan, efisiensi pakan, dan aktivitas enzim amilase pada benih ikan bandeng. Kandungan karbohidrat 30,4\%(dektrin $27,0 \%$ dal am pakan adalah optimal untuk mendukung laju pertumbuhan, efisiensi pakan, dan aktivitas enzim amilase pada lambung dan pada usus ikan bandeng. 


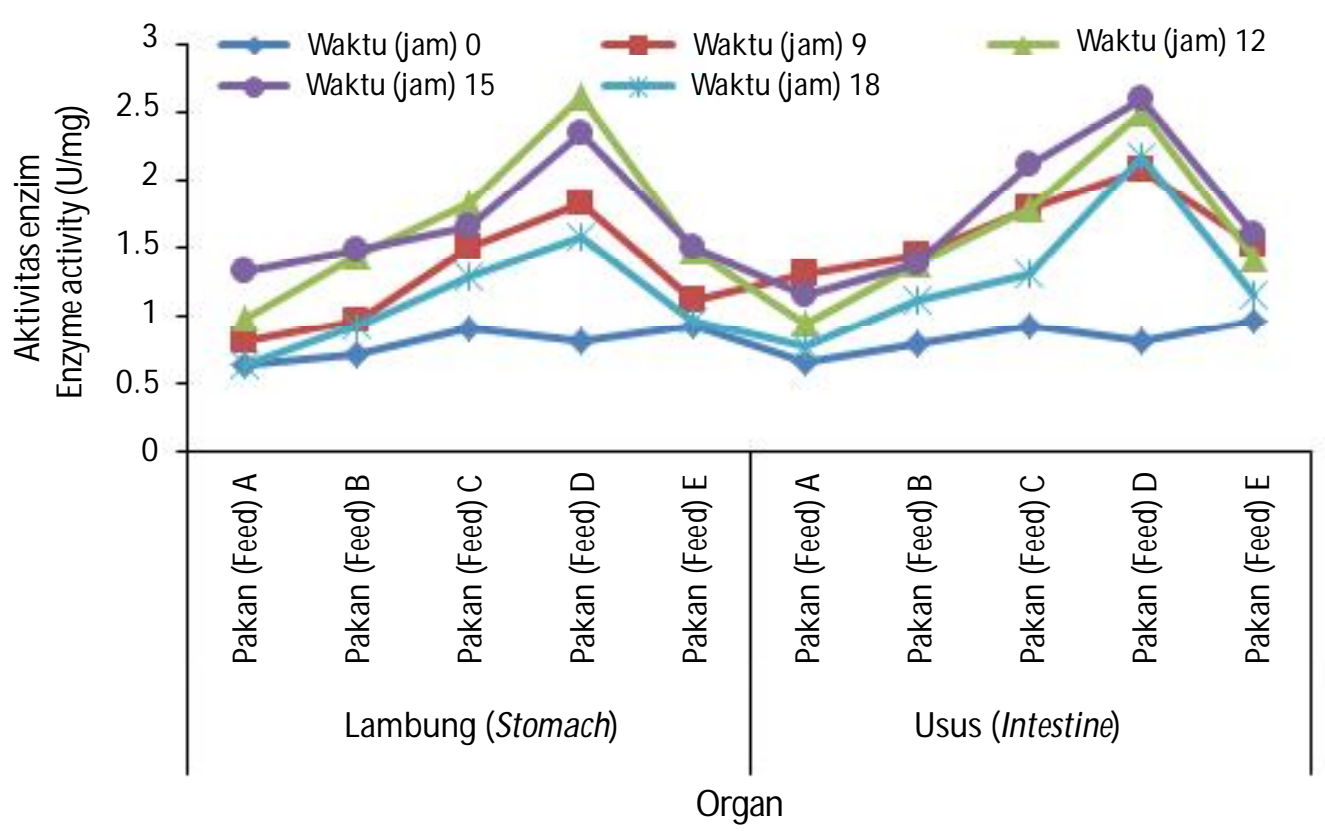

Gambar 1. Aktivitas enzim amilase pada lambung maupun usus ikan bandeng (Chanos chanos Forsskal) yang diberi pakan dengan kandungan karbohidrat yang berbeda.

Figure 1. The activity of amylase enzymes in the stomach and intestines of milkfish (Chanos chanos Forsskal) fed with diets containing different carbohydrate dosages.

Tabel 3. Kisaran parameter kualitas air selama penelitian

Table 3. Range of water quality during experiment

\begin{tabular}{lcccccc}
\hline \multirow{2}{*}{$\begin{array}{c}\text { Pakan (kadar karbohidrat) } \\
\text { Diets (carbohydrate levels) } \\
\text { (\%) }\end{array}$} & $\begin{array}{c}\text { Oksigen terlarut } \\
\text { Dissolved oxygen } \\
\text { (mg/L) }\end{array}$ & $\begin{array}{c}\text { Salinitas } \\
\text { Salinity } \\
\text { (ppt) }\end{array}$ & $\begin{array}{c}\text { pH } \\
\text { pHemperature } \\
\text { ('C) }\end{array}$ & $\begin{array}{c}\text { Amoniak } \\
\text { Tmmonia } \\
\text { (mg/L) }\end{array}$ & $\begin{array}{c}\text { Nitrit } \\
\text { Nitrite } \\
\text { (mg/L) }\end{array}$ \\
\hline A (3.4\%) & 6.2 & 35.0 & 8.2 & $25.8-28.1$ & 0.0084 & 0.004 \\
B (12.4\%) & 6.1 & 35.0 & 8.2 & $26.1-28.1$ & 0.0065 & 0.006 \\
C (21.4\%) & 6.2 & 35.0 & 8.2 & $26.1-28.0$ & 0.0075 & 0.004 \\
D (30.4\%) & 6.2 & 35.0 & 8.2 & $26.0-28.1$ & 0.0086 & 0.004 \\
E (39.4\%) & 6.1 & 35.0 & 8.2 & $25.7-28.0$ & 0.0075 & 0.009 \\
\hline
\end{tabular}

\section{UCAPAN TERIMA KASIH}

Ucapan terima kasih disampaikan kepada teknisi laboratorium Nutrisi dan Pengembangan Pakan pada Balai Besar Riset Budidaya Laut dan Penyuluhan Perikanan (Bapak Sumardi dan Bapak I Gusti Adi Kurniawan) yang telah membantu selama pelaksanaan penelitian ini.

\section{DAFTAR ACUAN}

Affandi, R., Sjafei, D.S., Raharjo, M.F., \& Sulistiono. (2005). Fisiologi ikan, pencernaan dan penyerapan makanan. Departemen Manajemen Sumberdaya
Perairan, Fakultas Perikanan dan IImu Kelautan, Institut Pertanian Bogor. Bogor, $215 \mathrm{hlm}$.

Afrianto, E. \& Liviawaty, E. (2005). Pakan ikan dan perkembangannya. Yogyakarta: Kanisius, hlm. 23-56.

Association of Official Analitical Chemists [AOAC]. (1990). Official methods of analysis. $12^{\text {th }}$ edition. Association of Official Analytical Chemists. Washington, D.C., 1141 pp.

Bagarinao, T.U. (1991). Biology of milkfish (Chanos chanos Forsskal). Philipine: Aquaculture Department Southeast Asian Fisheries Development Center, p. 1-105. 
Bluman, A.G. (2012). Elementary statistic: Step by Step Aproach. 8th Ed. America: McGraw-Hill, p. 45-208.

Boonyaratpalin, M. (1997). Nutrient requirements of marine food fish cultured in South Asia. Aquaculture Journal, 151, 283-313.

Brauge, Medale, C.F. \& Corraze, G. (1994). Effect of dietary carbohydrate levels on growth, body composition and glycaemia in rainbow trout, Oncorhynchus mukiss, reared in seawater. Aquaculture Journal, 123, 109-120.

Buwono, I.D. (2000). Kebutuhan asam amino essensial dalam ransum ikan. Yogyakarta: Kanisius, $55 \mathrm{hlm}$.

Castro, C., Corraze, G., Basto, A., Larroquet, L., Panserat, S., \& Oliva-Teles, A. (2016). Dietary lipid and carbohydrate interactions: implications on lipid and glucose absorption, transport in gilthead sea bream (Sparus aurata) juveniles. Lipids, 51, 1-13.

Cui, X.J., Zhou, Q.C., Liang, H.O., Yang, J., \& Zhao, L.M. (2010). Effects of dietary carbohydrate sources on the growth performance and hepatic carbohydrate metabolic enzyme activities of juvenile cobia (Rachycentron canadum Linnaeus). Aquac. Res., 42, 99-107.

Dorit, R.L., Walker, Jr.W.F., \& Barnes. (1991). Digestion and nutrition. In Zoology. USA: Saunders college Publishing, p. 235-259.

Enes, P., Peres, H., Couto, A., \& Oliva-Teles, A. (2010). Growth performance and metabolic utilization of diets including starch, dextrin, maltose or glucose as carbohydrate source by gilthead sea bream (Sparus aurata) juveniles. Fish Physiol. Biochem., 36, 903-910.

Erfanullah \& Jafri, A.K. (1995). Protein-sparing effect of dietary carbohydrate in diet for fingerling Labeo rohita. Aquaculture Journal, 136, 331-339.

Furuichi, M. (1988). Carbohydrates. In: Watanabe T. (Ed.). Fish Nutrition and Mariculture. Tokyo: Departement of Aquatic Biosciences, University of Fisheries, p. 44-55.

Gallego, M.G., Bazoc, J., Akharbach, H., Suarez, M.D., \& Sanz, A. (1994). Utilization of different carbohydrates by the European eel (Anguilla anguilla). Aquaculture Journal, 124, 99-108.

Hadadi, A. (2009). Pengaruh kadar karbohidrat pakan yang berbeda terhadap pertumbuhan dan efisiensi pakan ikan gurame (Osphronemus gouramy Lacepede). Tesis. Bogor, hlm. 35-36.

Hepher, B. (1988). Nutrition of pond fishes. New York: Cambridge University Press, 388 pp.
Infante, J.L.Z. \& Cahu, C.L. (2001). Ontogeny of the gastrointestinal tract of marine fish larvae. Comparative Biochemistry and Physiology Journal, Part C, 130, 477-487.

Lee, S.M., Kim, K.D., \& Lall, S.P. (2003). Utilization of glucose, maltose, dextrin and cellulose by juvenile flounder (Paralichthys olivaceus). Aquaculture Journal, 221, 427-438.

Lewis, R. (1998). Digestion and nutrition. In: Life. 3rd eds. USA: McGraw-Hill, p. 749-768.

Marlyn, L. \& Serrano A.E. (2014). Effect of cyclic feeding on compensatory growth in milkfish Chanos chanos juveniles. J. ELBA Bioflux Journal, 6(1), 2228.

Mashur. (2005) Kebutuhan Nutrisi Kerapu. http:// ntb.litbang.deptan.go.id/nutrisi.htm. 7 M ei 2006.

McFadden, C.H. \& Keeton, W.T. (1995). Nutrition procurement in heterotrophic organism. In: Biology, an exploration of life. USA: Cornell University: W.W. Norton and Company, p. 343-372.

Melianawati, R. (2009). Aktivitas enzim pencernaan larva ikan kerapu (Epinephelus fuscoguttatus Forsskal, 1775) terkait dengan perbedaan jenis pakan. Tesis. Yogyakarta: Universitas Gadjah Mada, hlm. 17-24.

Moreira, I.S., Peres, H., Couto, A., Enes, P., \& OlivaTeles, A. (2008). Temperature and dietary carbohydrate level effects on performance and metabolic utilization of diets in European sea bass (Dicentrarchus labrax) juveniles. Aquaculture Journal, 274, 153-160.

Nelson, G.E. \& Robinson. (1982). Digestion, transport and respiration. In: Fundamental concepts of biology. 4th eds. USA: John Wiley and Sons, p. 95-112.

National Reseach Council [NRC], Subcommittee on Warm Fish Nutrition. (1983). Nutrient requirements of Warmwater fishes and shellfishes. Washington, D.C.: National Academy Pr., p. 1-30.

Peres, H. \&. Oliva-Teles. P.A. (1999). Glucose tolerance in gilthead seabream (Sparus aurata) and European sea bass (Dicentrarchus labrax). Aquaculture Journal, 179, 325-334.

Podoskina, T.A., Podoskina, A.G., \& Bekina, E.N. (1997). Efficiency of utilization of some potato starch modifications by rainbow trout (Oncorhynchus mykiss). Aquaculture Journal, 152, 235-248.

Purves, W.K., Orians, G.H., \& Heller, H.C. (1992). Animal nutrition. In: Life: the science of biology. Sinauer Assc., p. 935-961. 
Ren, M., Tsion, H.M.H., Xie, J., Liu, B., Zhou, Q., Ge, X., Pan, L., \& Chen, R. (2015). Effects of dietary carbohydrate source on growth performance, diet digestibility and liver glucose enzyme activity in blunt snout bream, Megalobrama amblycephala. Aquaculture journal, 438, 75-81.

Shiau, S.Y. (1997). Utilization of carbohydrates in warmwater fish-with particular reference to tilapia, (Oreochromis niloticus x M. Saxatilis 0). Aquaculture Journal, 161, 201-212.

Shiau, S.Y. \& Chuang, J.C. (1995). Utilization of disaccarides by juvenile tilapia, Oreochromis niloticus $x$ 0. Aureus. Aquaculture Journal, 133, 249-256.

Sutikno, E. (2011). Pembuatan pakan buatan ikan bandeng. Jepara: Direktorat Jenderal Perikanan Budidaya Balai Besar Pengembangan Budidaya Air Payau Jepara, p. 1-34.

Suwirya, K., Giri, N.A., Marzuqi, M., \& Tridjoko. (2002). Kebutuhan karbohidrat untuk pertumbuhan yuwana ikan kerapu bebek, Cromileptes altivelis. Jurnal Penelitian Perikanan Indonesia, 8(2), 9-14.

Starr, C. \& Taggart R. (1995). Digestion and human nutrition. In Biology, the unity and diversity of life. 7th eds. England: Wadsworth Publishing, p. 714-730.

Takeuchi, T. (1988). Laboratory work, chemical evaluation of dietary nutrients. In Watanabe, T. (Ed). Fish Nutrition and M ariculture. Tokyo: Departement of Aquatic Biosciences, University of Fisheries, p. 179-288.

Tan, Q., Xie, S., Zhu, X., Lei, W., \& Yang, Y. (2006). Effect of dietary carbohydrate sources on growth performance and utilization for gibel carp (Carassius auratus gibelio) and Chinese longsnout catfish (Leiocassis longirostris Günther). Aquac. Nutr., 12, 61-70.

Usman. (2002). Pengaruh jenis karbohidrat terhadap kecernaan nutrien pakan, kadar glukosa darah, efisiensi pakan dan pertumbuhan yuwana ikan kerapu tikus (Cromileptes altivelis). Tesis. Program Pascasarjana, Institut Pertanian Bogor. Bogor, 74 hlm.

Wallace, R.A., Sanders, G.P., \& Ferl, R.J. (1996). Digestion and nutrition. In Biology, the science of life. 4th eds. Harper Collin Publish, p. 788-811.

Watanabe, T. (1988). Fish nutrition and mariculture JICA texbook. The General Aquaculture Course. Japan: Departement of Aquatic Biosiences, Tokyo University of Fisheries. Japan, 233 pp.

Wedemeyer, G.A. (1996). Physiology of fish in intensive culture system. US: Springer, 226 pp.

Wilbraham, A.C. \& Matta, M.S. (1992). Pengantar kimia organik dan hayati. Bandung: Institut Teknologi Bandung, $98 \mathrm{hlm}$.

Wilson, R.P. (1994). Utilization of dietary carbohydrate by fish. Aquaculture Journal, 124, 67-80.

Winarno, F.G. (1997). Kimia pangan dan Gizi. Jakarta: Gramedia Pustaka Utama, p. 12-67.

Yamin, M., Palinggi, N.N., \& Rachmansyah. (2008). Aktivitas enzim protease dalam lambung dan usus ikan kerapu macan setelah pemberian pakan. Media Akuakultur, 3(1), 40-44.

Yulintine. (2012). Upaya peningkatan kelangsungan hidup larva ikan betok Anabas testudineus Bloch melalui studi ontogeni sistem pencernaan, kemampuan biosintesis HUFA dan pengkayaan asam lemak esensial. Disertasi. Bogor: Sekolah Pascasarjana Institut Pertanian Bogor. Bogor, 41 pp. 